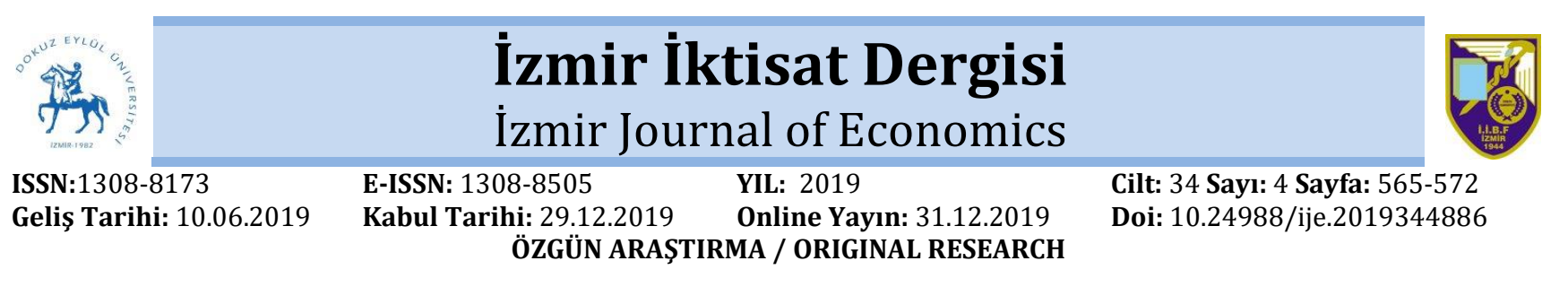

\title{
The Role of Money in Turkish Economy
}

\author{
Hasan ŞAHIN 1 , Ümit KOÇ ${ }^{2}$ \\ Abstract
}

A well functioning monetary policy requires the knowledge of the effects of monetary aggregates on output and inflation. In this study, we try to analyze the role of money in a monetary business cycle model in the case of Turkey during the 20062017 period. Estimation results of the structural model are also compared with single equations' estimation results and it is found out that the results of the structural model and single equations are quietly different. The differences show that the results of single equation estimations should cautiously be interpreted. In the model, it is found out that real balances have effects on IS and Philips curves.

Key Words: Monetary Aggregates, Monetary Policy, Business Cycle Model, New Keynesian Model JEL Classification: C22, C61, E12, E52

\section{Türkiye Ekonomisinde Paranın Rolü Özet}

İyi işleyen bir para politikası için parasal büyüklüklerin çıktı ve enflasyon üzerindeki etkisine ilişkin bilgiye ihtiyaç duyulmaktadır. Bu çalışmada, Türkiye için 2006-2017 döneminde parasal iş çevrimi modelinde paranın rolü analiz edilmektedir. Çalışmada yapısal modele ilişkin tahmin sonuçları, tek denklemli tahmin sonuçları ile de karşılaştırılmakta ve her iki yaklaşımdaki tahmin sonuçlarının farklı olduğu sonucuna ulaşılmaktadır. Bu farklılıklar tek denklemli model tahmin sonuçlarının oldukça ihtiyatlı bir şekilde değerlendirilmesinin gerekliliğine işaret etmektedir. Modelde reel balansların hem IS hem de Philips eğrileri üzerinde etkisi olduğu sonucuna ulaşılmıştır.

Anahtar Kelimeler: Parasal Büyüklükler, Para Politikası, İş Çevrimi Modeli, Yeni Keynesyen Model JEL Sinıflandırması: C22, C61, E12, E52

\section{INTRODUCTION}

Monetary policy evaluation and transmission of policy effects are two important processes of a business cycle. During the last thirty years, particularly beginning from the "inflationtargeting" period, in many academic studies New Keynesian models have been used for achieving the implementation of the right monetary policy. In this framework, central banks set the interest rate to be able to reach the required policy objective such as low inflation. In other words as a monopoly, they set the price of money and then supply the quantity demanded at that price to affect the main macro variables. But how about the effect of money stock in monetary policy and monetary transmission? More clearly, does real or nominal money stock affect the behavior of other macro variables? In most of these models, monetary aggregates do not affect behavioral equations.

The main motivation of this study is to identify if money has any role in the monetary business cycle for Turkey. For this purpose, the monetary business cycle model, which is developed by Ireland (2004), is used for examining the role of money in Turkey for the period from 2006:Q1 to 2017:Q2. As mentioned in Ireland (2004), there are many studies with different models and assumptions (Rotemberg and Woodford (1997), McCallum and Nelson (1999), Rudebusch and Svensson (2002), Fuhrer and Moore (1995)) which have a common point that gives a minimal role to changes in money stock. In many models, real or nominal balances do not affect the behavioral dynamics of other macro variables such as output and inflation. In our study, we

\footnotetext{
1 Prof. Dr., Ankara Üniversitesi, Siyasal Bilgiler Fakültesi, İktisat bölümü, Ankara

EMAIL: hasan.sahin@politics.ankara.edu.trＯORCID: 0000-0001-5922-068X

2 Dr., Uzman, Türkiye Cumhuriyet Merkez Bankası, Ankara,

EMAIL: umit.koc@tcmb.gov.tr

ORCID: 0000-0002-1853-5156
} 


\section{ŞAHIN H. - KOÇÜ.}

discuss this issue and ask the question: "Is this the way that life goes on?"

Ireland (2004) constructed a small structural model in which real money stocks have an effect on output and inflation. In the model, the household's utility function is nonseparable across consumption and real balances. With the nonseparability of consumption and real balances, the real money stock parameter enters into both IS and Philips Curve equations. By this way, the characteristics of the model imply that the effects of real balances on output and inflation come from IS and Philips Curve equations.

In order to see the direct and correct effects of the monetary transmission mechanism and the role of real balances in the real economy through IS and Philips Curve, it is crucial to obtain a consistent and unbiased estimate of the real money stock coefficient. For isolating the effects of money demand disturbances on the economy and getting an unbiased estimate of real money stock coefficient, the monetary authority controls short term interest rates with giving ability to changes in money supply (for tolerating the changes in money demand) while trying to keep output and inflation unaffected from changes in money demand. So that it becomes possible to quantify the effects of real balances on output and inflation.

The 1990s were the years of high inflation in Turkey. This high inflation period ended up with the 2001 crisis which was a critical moment for the Turkish economy. Following the 2001 crisis, several financial and structural measures were put on the agenda of the reform program of Turkey. Changing the exchange rate regime from pegged to floating, enabling the financial discipline, amending the Central Bank of Republic of Turkey (CBRT) law, and introducing measures for banking sector were the pillars of these reforms (The details of these structural reforms in monetary policy can be found in CBRT web site: www.tcmb.gov.tr).

With the amendment of the CBRT law, price stability has become the primary objective of the bank. During the 2002-2005 period, the
CBRT established a monetary policy that was characterized by implicit inflation targeting. In this period CBRT succeeded to decrease the inflation rate to \% 8-9. In 2006 CBRT began to execute direct inflation targeting regime. In 2010, following the global financial crisis, the CBRT adopted a dual mandate policy of financial stability and price stability. For the implementation of financial stability policy, the CBRT introduced an unorthodox policy framework in which multiple policy rates could be implemented within a wide interest rate corridor. With the new interest rate corridor policy, the CBRT also developed instruments based on reserve requirements which were named "Reserve Option Mechanism". The CBRT used the interest rate corridor until the end of May 2018 and from that date on, the CBRT simplified the interest rate policy and returned to the single policy rate.

With this introduction, our paper has the following sections: In the next section, we present the main parts of the theoretical model. In Section 3, we evaluate the data set and the empirical results and finally in Section 4, we provide some policy implications and suggestions for future studies.

\section{THEORETICAL BACKGROUND and THE MODEL}

There is a huge literature on the e role of money in monetary business cycle. We will summary of some of the selected literature. Sims (1983) concludes his article by highlighting the probable absence of a monetarist business cycle. It is emphasized that the absence of a monetarist business cycle does not have the same meaning with the phrase "no influence of monetary policy on the business cycle".

Rudebusch and Svensson (2002) uses a backward looking model and makes an empirical test of the effects of nominal money on output and inflation. In the empirical analysis with US data, they find that nominal money has no effect on these two variables. Andres, Lopez-Salido, and Nelson (2009) states that in a forward looking New Keynesian model money has very little role statistically and in 
fact which is negligible in practice. Canova and Menz (2011) explores if money amplifies the cyclical fluctuations to output and inflation. The study uses maximum likelihood estimation technique in the empirical analysis. It is found that money is statistically significant for the fluctuation in output and inflation. Money's effect comes from directly from the Euler equation and Philips curve and indirectly from the nominal interest rate channel. It is shown that the role of money is not constant over time. Its magnitude and statistical significance are changing over time.

Castelnuovo (2012) uses a sticky price New Keynesian model with money. It is concluded that money has a significant role in US business cycles and this role is time varying. In Andres, Lopez-Salido, and Valles (2006) with a model that uses Euro data, shows that money has a little role in the business cycle. The model also contains habit formation and price indexation. The empirical findings in this study confirm Ireland's (2004) results with euro data.

Favara and Giordani (2009) uses a VAR approach to quantify the effects of broad monetary aggregates and it is found that money should be neglected in New Keynesian small scale macroeconomic models. Araujo (2015) finds out that money is significant in estimated Taylor rules since it gives information especially in forecasting inflation and the output gap. In the empirical analysis evidence supporting the presence of money is found in private agents' behavior that indicates the importance of money in business cycles. Zanetti (2012) investigates the role of money in the business cycle with a New Keynesian model. The model is extended with a banking sector in which bank deposits are used to finance consumption. Estimation of the model with the maximum likelihood method shows that money has a significant role in explaining the intertemporal allocation of consumption and the dynamics of inflation. On the other hand, applying the impulse response functions it is seen that the model's variables' responses to shocks are almost the same in cases of money's absence and presence. Fujiwara (2007) uses a DSGE model in which the effects of money stem from the non-separability of utility in consumption and real balances. The maximum likelihood estimates of the model do not support the significance of money in the business cycle for Japan.

In our study, we follow Ireland (2004)'s model to see the effects, if any exists, of the money stock in a monetary business cycle model in Turkey. We present the main equations of the model since the details and a complete solution of the model is already there, in Ireland (2004).

$\hat{y}_{t}=E_{t} \hat{y}_{t+1}-\omega_{1}\left(\hat{r}_{t}-E_{t} \hat{\pi}_{t+1}\right)+\omega_{2}\left[\left(\hat{m}_{t}-\hat{e}_{t}\right)-\left(E_{t} \widehat{m}_{t+1}-E_{t} \hat{e}_{t+1}\right)\right]+\omega_{1}\left(\hat{a}_{t}-E_{t} \hat{a}_{t+1}\right)$

$\hat{m}_{t}=\gamma_{1} \hat{y}_{t}-\gamma_{2} \hat{r}_{t}+\gamma_{3} \hat{e}_{t}$

$\hat{\pi}_{t}=\left(\frac{\pi}{r}\right) E_{t} \hat{\pi}_{t+1}+\psi\left[\left(\frac{1}{\omega_{1}}\right) \hat{y}_{t}-\left(\frac{\omega_{2}}{\omega_{1}}\right)\left(\hat{m}_{t}-\hat{e}_{t}\right)\right]-\hat{z}_{t}$

In equations $1-3 ; \hat{y}_{t}, \hat{m}_{t}, \hat{\pi}_{t}, \hat{r}_{t}, \hat{a}_{t}, \hat{e}_{t}$, and $\hat{z}_{t}$ (aggregate demand, money demand, inflation rate, interest rate, household's preference shock, money demand shock and technology shock, respectively) are the percentage deviations of the variables from their steadystate values. Equations 1, 2, and 3 correspond to IS, money demand and the Philips curve respectively. In the system of equations, $E_{t}$ operand stands for an expectation operator.
The interest rate rule for monetary policy is given by equation (4):

$\hat{r}_{t}=\rho_{r} \hat{r}_{t-1}+\rho_{y} \hat{y}_{t-1}+\rho_{\pi} \hat{\pi}_{t-1}+\varepsilon_{r t}$

Preference shocks $\hat{a}_{t}$ and $\hat{e}_{t}$ are given by equations (5) and (6);

$$
\begin{aligned}
& \ln \left(a_{t}\right)=\rho_{a} \ln \left(a_{t-1}\right)+\varepsilon_{a t} \\
& \ln \left(e_{t}\right)=\left(1-\rho_{e}\right) \ln (e)+\rho_{e} \ln \left(e_{t-1}\right)+\varepsilon_{e t}
\end{aligned}
$$




\section{ŞAHIN H. - KOÇÜ.}

Finally, aggregate productivity shock $z_{t}$ is given by equation (7);

$\ln \left(z_{t}\right)=\left(1-\rho_{z}\right) \ln (z)+\rho_{z} \ln \left(z_{t-1}\right)+\varepsilon_{z t}$

$\varepsilon_{r t}, \varepsilon_{a t}, \varepsilon_{e t}$, and $\varepsilon_{z t}$ represent random shocks with normal distributions. In this small New Keynesian model, real money balances enter both in the forward-looking IS curve (1) and the Phillips curve (3). Aggregate demand $\hat{y}_{t}$ is characterized by a representative utility maximizing household and household's utility function, which is nonseparable between consumption and real balances. When this nonseparability occurs, the household's marginal rate of substitution between consumption and leisure (which are separable) is linked to the real interest rate. And by the nonseparability assumption real balances enter into the aggregate demand curve, since real balances affect the marginal rate of intertemporal substitution between current and future consumption. In the aggregate supply curve (3) side a final good producing representative firm uses labor and intermediate goods with constant returns to scale technology for final goods production. However, the intermediate good producer firm uses only labor for production. This representative intermediate good producing firm is the price setter, as it has monopolistic power in the market. In the optimizing process with the non-separability of real balances and consumption, real balances enter into the aggregate supply curve. As emphasized in Ireland (2004) if the real balances variable enter into the aggregate demand curve, it should also enter into the aggregate supply curve. The money demand relationship is given by equation (2) with the specifying parameters of aggregate demand, interest rate, and money demand shock.

The monetary authority follows a Taylor type interest rate rule (equation 4) which captures interest rate inertia with a lagged interest rate. By this rule, the monetary authority sets the interest rate following the deviations of output and inflation from their steady-state levels. The lagged interest rate variable in the equation causes interest rate smoothing mechanism, in which adjustment of interest rate to output ve inflation deviations is gradual.

Equations 5-7 specify the stochastic disturbances for the preference, money demand and productivity shocks that follow AR (1) processes.

Besides our main aim, we estimate the above structural form along with the single equation form, which is commonly done in empirical works, to evaluate sensitivities of estimated parameter values.

\section{DATA SET AND EMPIRICAL RESULTS}

Using equations 1-7, parameter estimations have been performed by using the maximum likelihood method. Our data set consists of output, real money balances, inflation, and the nominal interest rate. We measure output by real gross domestic product (GDP). The real balances variable is calculated by dividing money supply (M1) by the GDP deflator, inflation is measured by the percentage change in the consumer price index, and finally, the interest rate is the 3-month-time deposit rate. We use the quarterly data set running between 2006:Q1 and 2017:Q2. The model is characterized by the preference shock, real money balances preference shock, productivity shock, and the monetary policy rule. The descriptive statistics of the variables are given in Table-1. All the variables are stationary and to save space we did not provide the stationary test results.

Table-1: Descriptive Statistics of Model's Variables

\begin{tabular}{lcccc}
\hline & $\begin{array}{c}\text { Log } \\
\text { Output }\end{array}$ & $\begin{array}{c}\text { Log Real } \\
\text { Balances }\end{array}$ & $\begin{array}{c}\text { Inflation } \\
\text { (\%) }\end{array}$ & $\begin{array}{c}\text { Interest } \\
\text { Rate (\%) }\end{array}$ \\
Mean & 26.45263 & 21.01621 & 1.9516 & 12.09457 \\
Median & 26.44929 & 21.03003 & 1.7696 & 10.67667 \\
Maximum & 26.75755 & 21.60230 & 8.9333 & 19.99333 \\
Minimum & 26.21592 & 20.55647 & -.2 .4073 & 6.766667 \\
Standart & & & & \\
Deviation & 0.177385 & 0.342607 & 2.0105 & 3.828429 \\
& & & & \\
\hline
\end{tabular}

We use a customized MATLAB code of Ireland (2004). We run the code with different initial values and find out that the results are very sensitive to initial values. After running more 
than 200 different initial values set, we get the most appropriate (global) solution for the model which is provided in Table- 2 .

According to estimation results, $\ln (y), \ln (m)$, (p) and (r) are close to their sample average values. The estimate of $\rho_{a}$ which is the shock to IS via household's preference change; is high. The numerical value of $\rho_{a}$ indicates the persistence of the IS shock. The estimate of $\rho_{\mathrm{e}}$, which shows the effect of the money demand shock, is 0.92 and also persistent. Finally, the productivity shock $\rho_{\mathrm{z}}$ is 0.17 but it is statistically insignificant. The values of $\rho_{a}$ and $\rho_{e} \quad$ estimates are high and the persistence effects are similar to that of Ireland (2004)'s. The values of $\sigma_{\mathrm{a}}$ and $\rho_{\mathrm{e}}$ estimates show the importance of exogenous shocks to IS and money demand.

Table-2: Estimation Results

\begin{tabular}{ccc}
\hline Parameter & Estimate & $\begin{array}{c}\text { Standard } \\
\text { Error }\end{array}$ \\
\hline $\boldsymbol{\omega}_{\mathbf{2}}$ & $0.011259^{*}$ & $1.13 \mathrm{E}-12$ \\
$\boldsymbol{\gamma}_{\mathbf{1}}$ & $0.404223^{* *}$ & 0.164207 \\
$\boldsymbol{\gamma}_{\boldsymbol{2}}$ & $3.903067^{* *}$ & 1.558697 \\
$\boldsymbol{\gamma}_{\mathbf{3}}$ & $0.768656^{*}$ & 0.089077 \\
$\boldsymbol{\rho}_{\boldsymbol{r}}$ & $0.916505^{*}$ & $8.63 \mathrm{E}-05$ \\
$\boldsymbol{\rho}_{\boldsymbol{y}}$ & $0.044647^{*}$ & 0.010384 \\
$\boldsymbol{\rho}_{\boldsymbol{\pi}}$ & $0.076939^{*}$ & $8.63 \mathrm{E}-05$ \\
$\boldsymbol{l n}(\boldsymbol{y})$ & $21.64026^{*}$ & 0.009144 \\
$\boldsymbol{l n}(\boldsymbol{m})$ & $20.32816^{*}$ & 0.057993 \\
$\boldsymbol{p}$ & $0.038388^{*}$ & $1.76 \mathrm{E}-23$ \\
$\boldsymbol{r}$ & $0.057582^{*}$ & 0.001038 \\
$\boldsymbol{\rho}_{\boldsymbol{a}}$ & $0.966482^{*}$ & 0.010612 \\
$\boldsymbol{\rho}_{\boldsymbol{e}}$ & $0.926837^{*}$ & 0.065118 \\
$\boldsymbol{\rho}_{\boldsymbol{z}}$ & 0.177276 & 0.130856 \\
$\boldsymbol{\sigma}_{\boldsymbol{a}}$ & $0.078461^{*}$ & 0.011456 \\
$\boldsymbol{\sigma}_{\boldsymbol{e}}$ & $0.030681^{*}$ & 0.004767 \\
$\boldsymbol{\sigma}_{\boldsymbol{z}}$ & $0.208306^{*}$ & 0.030600 \\
$\boldsymbol{\sigma}_{\boldsymbol{r}}$ & $0.002352^{*}$ & 0.000258 \\
\hline
\end{tabular}

(*) : Significant in $1 \%$.

(**): Significant in $5 \%$.

Log likelihood: 523.0877

The key parameter of this study $\omega_{2}$ is found as 0.011 and this means that the real balances variable has an effect on IS and Philips curves. Similar to our findings Favara and Giordani (2009), Poily (2010), Canova and Menz (2011), Zanetti (2012) find that real balances have persistent effects on output and inflation suggesting that the real balances have a role in the business cycle. Also, Kremer and et al. (2006) found that real balances affect both output and inflation dynamics for Germany. On the other hand, findings of Ireland (2004) and Andres and et al. (2006) suggest that real balances have no effect on IS and Philips curves. Therefore, whether there is a real balance effect on the variables of interest is an empirical issue.

Money demand plays a vital role in selecting the appropriate or right monetary policy action. According to our estimation results, the income elasticity of money demand is 0.4042 . In Ireland (2004) this parameter is 0.0138 which is quite small compared to our findings. Based on our estimation results, we can say that economic activity and output changes lead to higher changes in money demand in Turkey. We find interest rate elasticity of money demand 3.903 which is a high value but can be traced in economies with high inflation rates, and low saving ratios. Ericcson and Sharma (1998) found income elasticity of money demand 1.22 for Greece, Muscatelli, and Papi (1990) found the same elasticity as 1.367 for Italy, Orden and Fisher (1993) found 0.63 for New Zealand. Bahmani-Oskooee and Karacal (2006) found the income elasticity of money demand as 0.26 and interest rate elasticity as 0.27 for Turkey using narrow money supply M1. Tümtürk (2017) found the income elasticity ranging from 0.65 to 0.76 and the interest rate elasticity ranging from -0.62 to 0.63 and finally Oktayer (2011) found the elasticities as 3.79 (this value is very close to our finding) and -0.27 respectively for Turkish money demand.

When we explore the Philips Curve equation, we see that the effect of the expected rate of inflation on the current inflation rate is very high. This finding points to the importance of management of expectations and monetary authority's communication skills.

In the interest rate rule (equation 4) the estimate of the lagged interest rate coefficient is 0.917 and indicates an inertia in interest rate. Compared to the lagged interest rate coefficient, the output gap and inflation coefficients seem to be smaller with the values of 0.045 and 0.077 . The main determinant of monetary authority's reaction function (in an 


\section{SAHIN H. - KOC Ü.}

inflation targetting economy) is the lagged interest rate. According to our findings, the monetary authority is not strictly reactive to inflation in the short run as it is seen in the small estimated value of the inflation coefficient. However, the increase in the interest rate is more than the increase in inflation in the long run. As a result, the higher long term real interest rate prevails. These results are, we believe, consistent with the actual economic position of Turkey. In order to cover the domestic savings deficit with foreign savings, the policymakers choose higher real interest rate policies. With the higher real interest rates, Turkey faces a more valuable local currency, relatively lower investment growth and higher import rates and as a result of all, an unsustainable GDP growth.

We add one further step to our study to check the sensitivity of results. For this purpose, we estimate IS Curve, LM curve, Philips curve and Interest Rate Rule equations with a single equation framework. The estimation results are given in Table-3.

Table-3: Single Equation Estimation Results

\begin{tabular}{|c|c|c|c|c|}
\hline \multirow{2}{*}{$\begin{array}{c}\text { EQUATIONS } \\
\text { IS Curve }\end{array}$} & \multicolumn{3}{|c|}{ SINGLE EQUATION VARIABLES } & \multirow[b]{2}{*}{$E_{t} \widehat{m}_{t+1}$} \\
\hline & $\hat{r}_{t}$ & $E_{t} \widehat{\pi}_{t+1}$ & $\widehat{m}_{t}$ & \\
\hline & $\begin{array}{c}0.2338 \\
(*)\end{array}$ & 0.057947 & $\begin{array}{c}0.160642 \\
(* * *)\end{array}$ & $\begin{array}{c}-0.246962 \\
\left(^{*}\right)\end{array}$ \\
\hline IM Curve & $\hat{y}_{t}$ & $\hat{r}_{t}$ & & \\
\hline Livi Curve & $\begin{array}{c}0.909528 \\
\left({ }^{*}\right)\end{array}$ & $\begin{array}{c}-0.513515 \\
(* *)\end{array}$ & & \\
\hline Philins Curve & $E_{t} \hat{\pi}_{t+1}$ & $\hat{y}_{t}$ & $\widehat{m}_{t}$ & \\
\hline & $\begin{array}{c}0.955035 \\
(* *)\end{array}$ & 0.079619 & -0.044823 & \\
\hline & $\hat{r}_{t-1}$ & $\widehat{y}_{t-1}$ & $\widehat{\pi}_{t-1}$ & \\
\hline Rule & $\begin{array}{c}0.813 \\
(*)\end{array}$ & $\begin{array}{c}0.160398 \\
(*)\end{array}$ & $\begin{array}{c}0.217553 \\
\left({ }^{*}\right)\end{array}$ & \\
\hline
\end{tabular}

With the same data set, we see that some of the coefficients are insignificant at a $10 \%$ significance level. According to the single equation framework, we find $\omega_{2}$ approximately 0.08632 (the coefficients of current and expected real balances). In the first part of our study, we find $\omega_{2}=0.011259$, which means that money has a role in the monetary business cycle and with single equation framework we also get a $\omega_{2}$ value that is different from 0 and confirm the same result that real balances have a role in the monetary business cycle.

We find that inflation (in IS Curve) is statistically insignificant in the single equation framework, (while it is significant at a $1 \%$ significance level in the structural model). In the LM Curve side, we find the interest rate elasticity of money demand as 0.51 while in the first part that is 3.90. For the Philips curve side except for the inflation, all the other variables' coefficients are statistically insignificant.

For the interest rate rule, the coefficient of lagged interest rate is found as 0.813 which is lower than the structural model but still relatively high value. Both the inflation and output gap coefficients are higher than the structural model. When we look at the stance of monetary authority we see almost the same policy actions with the structural model. Monetary authority is not very responsive in the short run. But in the long run, the nominal interest rate increases more than inflation and it consequently causes a higher real interest rate. Compared to the structural model the output gap coefficient is higher and change in the real interest rate is lower. For the single equation estimation, almost all the coefficients are different from the structural model's coefficients. These results suggest that the use of single equations for parameter estimations should be avoided, if possible when the equation is a part of a structural equation system.

\section{CONCLUSION}

In this study, our aim is to investigate if money has any role in a monetary business cycle model. According to New Keynesian literature, real balances' role in cyclical fluctuations is minor. We follow Ireland (2004) model for estimating the Turkish data for the 2006-2017 period. Unlike Ireland (2004), we find that money has a role in the monetary business cycle model. In our estimate, we find that IS shock arising from household's preferences is a major factor as expected. The effect of this 
shock is also quite persistent. We also estimate real balances' coefficients with a single equation framework and find that this value is statistically different from zero again. So we confirm the role of money once more.

Estimation results show that in the short run, the monetary authority is not so reactive to the inflation and the output gap. However, in the long run, the reaction is clear. The results suggest that an increase in the real interest rate, ending up with more real appreciation in the local currency, would lead to relatively lower investment growth and higher import rates and as a result unsustainable GDP growth. These findings are consistent with the position of Turkey's monetary policy for the analysis period.

For the monetary authority's reaction function, we notice that there is an interest rate inertia that policymakers should consider this effect in an inflation targeting economy. According to our findings, the Turkish economy also gives importance to the output gap. But both inflation and output stabilizing process is very slow and the effectiveness of the policy rule is on the debate. This result must be taken into consideration by firms and households while taking critical actions or making critical changes as an economic agent.

The study also compares the results of structural model estimation with the results of single equation estimation. The findings of the structural model and the single equation model are quite different. Studies using a smaller part of structural models will probably lead to misinterpretations. Therefore, taking one equation from a structural model and estimating it as a single equation is not an appropriate way, as it is well known from the simultaneous equation estimation framework.

\section{REFERANSLAR}

Andres, J., Lopez-Salido, D., and Nelson, E. (2009). "Money and the Natural Rate of Interest: Structural Estimates for the United States and the Euro Area", Journal of Economic Dynamics and Control, 33, 758-776.

Andres, J., Lopez-Salido, J.D., and Valles, J. (2006), "Money in an Estimated Business Cycle Model of the Euro Area", Economic Journal,116, 457-477.

Araujo, E. (2015). "Monetary policy objectives and Money's role in U.S. business cycles", Journal of Macroeconomics, 45, 85-107.

Bahmani-Oskooee, M., and Karacal, M. (2006), "The Demand for Money in Turkey and Currency Substitution", Applied Economics Letters, 13(10), 635-642.

Canova, F., and Menz, T. (2011), “Does money matter in shaping domestic business cycles? An international investigation", Journal of Money, Credit and Banking, 43, 577-609.

Castelnuovo, E. (2012). "Estimating the Evolution of Money's Role in the U.S. Monetary
Business Cycle", Journal of Money, Credit and Banking, 44(1), 23-52.

Ericsson, N. R., and Sharma, S. (1998), "Broad Money Demand and Financial Liberalization in Greece", Empirical Economics, 23(3), 417-436.

Favara, G., and Giordani, P. (2009), "Reconsidering The Role of Money for Output, Prices and Interest Rates", Journal of Monetary Economics, 56, 419-430.

Fuhrer, J. C., and Moore, G. R. (1995), “Monetary Policy Trade-offs and the Correlation between Nominal Interest Rates and Real Output", American Economic Review, 85, 219-239.

Fujiwara, I. (2007). "Is there a direct effect of money? Money's role in an estimated monetary business cycle model of the Japanese economy", Japan and the World Economy, 19, 329-337.

Ireland, P. (2004), “Money's Role in The Monetary Business Cycle", Journal of Money, Credit, and Banking, 36(6), 969-983.

Kremer, J., Lombardo, G., and Werner, T. (2003), "Money in a New Keynesian model estimated 


$$
\text { ŞAHIN H. - KOÇ Ü. }
$$

with German data", Deutsche Bundesbank, discussion paper n. 15/2003.

McCallum, Bennett T., and Nelson, E. (1999), "An Optimizing IS-LM Specification for Monetary Policy and Business Cycle Analysis", Journal of Money, Credit, and Banking, 31, 296316.

Muscatelli, V. A., and Papi, L. (1990), "Cointegration, Financial Innovation, and Modelling the Demand for Money in Italy", Manchester School of Economic and Social Studies, 58 (September), 242-259.

Oktayer, A. (2011), "Finansal Yenilikler ve Para Talebi”, Maliye Dergisi, 160(1), 351-368.

Orden, D., and Fisher, L.A. (1993), "Financial Deregulation and the Dynamics of Money, Prices, and Output in New Zealand and Australia", Journal of Money, Credit, and Banking, 25(May), 273-292.

Poilly, C. (2010), "Does money matter for the identication of monetary policy shocks: A DSGE perspective", Journal of Economic Dynamics and Control, 34, 3166-3191.
Rotemberg, J. J. (1982), "Sticky Prices in the United States", Journal of Political Economy, 90, 1187-1211.

Rotemberg, J. J., and Woodford, M. (1997), “An Optimization-Based Econometric Framework for the Evaluation of Monetary Policy", NBER Macroeconomics Annual 1997, (Ed. Ben S. Bernanke and Julio J. Rotemberg), Cambridge, MA: MIT Press, 297-346.

Rudebusch, G. D., and Svensson, L.E.O. (2002), "Eurosystem Monetary Targeting: Lessons from U.S. Data", European Economic Review, 46, 417-442.

Sims, C. (1983). "Is There a Monetary Business Cycle", The American Economic Review, 73(2), 228-233.

Tümtürk, 0. (2017), "Stability of Money Demand in Turkey", Business and Economics Research Journal, 8(1), 35-48.

Zanetti, F. (2012), "Banking and the role of money in the business cycle", Journal of Macroeconomics, 34, 87-94. 